\title{
THE ENVIRONMENT OF THE PHLEGRAEAN FIELDS BETWEEN BIBLIOGRAPHIC AND ICONOGRAPHIC SOURCES
}

\author{
Matteo Borriello
}

\begin{abstract}
Since ancient times, the Phlegraean Fields were one of the most popular travel destinations.

For the particular geological characteristics of the territory, the nobility of ancient Rome built numerous pleasure villas, especially in the area between Pozzuoli, Baia and Bacoli, and later, in the modern and contemporary age, the travellers of the Grand Tour made the Phlegraean fields a real centre of tourism known all over the world. Over the centuries, through their travels, local and foreign scholars described the environment of the Phlegraean fields in their travel notebooks, often accompanied by sketches and drawings. In addition to these precious proofs, of particular interest are the articles published in the architecture and engineering periodicals within which projects of buildings are reported to be placed along the coastal strip, changing its original appearance.

Through the analysis of bibliographic, documentary and iconographic sources, such as the guides of monsignor Pompeo Sarnelli, "La Guida de' forestieri, curiosi di vedere, e di riconoscere le cose più memorabili di Pozzuoli, Baja, Cuma, Miseno, Gaeta. Ed altri luoghi circonvicini", and canon Andrea de Jorio, "Guida di Pozzuoli e contorno", the drawings of the French architect Prosper Barbot and the periodical "Bollettino del Collegio degli Ingegneri e Architetti in Napoli", this paper intends to illustrate the environment of the Phlegraean fields during the
\end{abstract}


XVIII and XIX centuries, making a comparison with the environment of the contemporary urban context. From the comparison of the sources it emerged how the image of the Phlegrean landscape has rapidly changed over the centuries. Today, most of the archaeological monuments and the same coastline are covered by a poor quality contemporary building, the result of the lack of control of the institutions, and which today gives the image of an environment of great but disordered beauty.

Keywords: Architecture, Environment, Image, Landscape, Phlegraean fields, Travel 


\section{INTRODUCTION}

The Phlegraean Fields have always been one of the most studied lands, the multifaceted nature of this environment has prompted the interest, since ancient times, of scholars and researchers belonging to different disciplines.

Already in the name the Phlegraean Fields, that is, the Burning Fields in which the ancient war between the titans and god Jupiter took place, show a fascination that led the ancient nobility of the Roman Empire to choose this area as a favourite site for the construction of numerous structures such as domus and thermal complexes, still visible despite the known phenomena of bradyseism, especially in the area between the centres of Pozzuoli, Baia and Bacoli.

A landscape in which the myth is intertwined with the geological and morphological nature of the place, already the first populations of Greek origin that colonized the area set the mythical battle in those places, fascinated by the particular volcanic phenomena (Di Liello 2005).

The Phlegraean Fields, therefore, thanks to the construction of the famous Portus Iulius and the strengthening of the port of Puteoli, now Pozzuoli, by the ancient romans, became a strategic territory from the military and above all, commercial, in close contact with the majority part of the merchant centres of the Mediterranean Sea (Di Liello 2009).

Over the centuries the articulated historical vicissitudes led to a slow decay of the whole territory, with a consequent political and economic isolation of the different centres of the area. In particular, the urban fabric of the city of Pozzuoli undergoes an incisive contraction, until it coincides with the extension of the centre of the medieval period with that of the foundation period perched on the promontory occupied by the present district called Terra (D’Ambrosio 1976).

In addition to the problems related to the incursions of the barbaric and Saracen populations, the Phlegrean territory underwent notable morphological changes related to the continuous volcanic and bradyseismic phenomena. In the Renaissance period there was a rapid rise in the soil which involved an expansion of the coastline and later the formation of the famous Monte Nuovo, the subject of news shortly after its emergence 
(Giamminelli 1987). In this context the writer Scipione Mazzella reports an interesting description of the event within his work Sito, et antichità della città di Pozzuolo, e del suo amenissimo distretto. Con la descrittione di tutti i luoghi notabili, e degni di memoria, e di Cuma, e di Baia, e di Miseno, e de altri luoghi convicini, of 1591:

\begin{abstract}
Monte nuovo, che fù fatto in un giorno, e una notte; poichè nell'anno 1538 à 29 di Settembre, essendosi per tutto il territorio di Pozzuolo, per alcuni giorni prima sentiti alcuni terremoti; con uno spaventevole tuono, e rimbombo, si aperse la terra qui à Tripergola, che parve che rovinasse tutt'il paese, essendo il cielo sereno, cominciarono ad uscire di questa apertura fiamme di fuoco conducendo seco cenere accompagnata con falsi affocati con gran fumo, e caligine (...) Aperta dunque la terra, e uscendo fiamme di fuoco con pietre, e cenere talmente intorno a detta apertura l'anti dette cenere composero con le pietre fangose le ruine che ne risultò il detto monte. Per tal' apertura, e compositione di monte, lo castello di Tripergole con gran parte del Lago Averno, e del Lucrino, e tutti quelli antichi e nobili edifizi, e la maggior parte di Bagni ch'erano intorno rimasero di sotto. (Mazzella 1591, 44-45)
\end{abstract}

The image of the Phlegrean territory, until then characterized by a composite urban structure and valuable buildings, gives way to a wild environment in which the natural element has almost completely concealed the ancient remains. Only between XVI and XVII centuries there is a partial reorganization of the area, above all centred in the area of Pozzuoli, an object of interest for the viceroys, like Don Pedro de Toledo who built a house there, and the foundation of some ecclesiastical buildings (D’Ambrosio 1976).

The interest in the Phlegraean Fields was rekindled in modern times thanks to those ancient ruins, now almost forgotten and also thanks to the continuous volcanic phenomena that distinguished the whole territory and which led to the arrival in those places of many travellers and scholars to analyse and admire these phenomena closely. Common travellers and specialized technicians such as architects and engineers, told the image of this changed landscape within their works as travel guides and notebooks. 
An unprecedented contribution is also provided by the architectural projects that have appeared in the specialized nineteenthcentury periodicals, which illustrate the progressive change in the Phlegrean landscape, which is still constantly changing.

\section{PHLEGRAEAN FIELDS IN TRAVEL LITERATURE}

A trip to the sea to Pozzuoli, short and happy walks in a carriage or on foot through the most prodigious country in the world. Under the clearest sky the most treacherous soil; rubble of inconceivable opulence, smoked, sinister; boiling waters, crevasses exhaling sulphur, mountains of slag rebels to every vegetation, barren and desolated spaces, and then, suddenly, an eternally luxuriant vegetable, which is everywhere where it can and rises above all this death, girdling ponds and streams, establishing itself with superb groups of this even on the sides of an ancient crater. (Goethe 1875, 206)

Since the XVIII century the Phlegraean Fields became an increasingly frequent destination within the Grand Tour, the continuous attention of travellers soon led to the drafting of a vast bibliographic corpus, largely consisting of travel guides to facilitate use of the Phlegrean territory. Often, these works were accompanied by a series of prints and engravings that contributed to spread the image of a bucolic and picturesque environment, embellished by archaeological ruins on which attention was concentrated not only to ordinary travellers but also to artists and architects.

The same Johann Wolfgang von Goethe does not give up a visit which is inserted in its path along with other known stages such as climbing to Vesuvius.

Among the numerous examples of historical guides relating to the area of the Phlegraean Fields, mention is made of that of bishop Pompeo Sarnelli, La Guida de' forestieri, curiosi di vedere, e di riconoscere le cose più memorabili di Pozzuoli, Baja, Cuma, Miseno, Gaeta. Ed altri luoghi circonvicini, published in 1784 as the fifth edition, and that of the canon Andrea de Jorio, Guida di Pozzuoli e contorno, of 1817. Both works had great resonance confirmed by the publication of several editions in the 
following years.

From the study of these bibliographic sources it is possible to notice how the journey had as its starting point the nearby city of Naples, to reach the Phlegrean area the traveller could cross the famous Crypta Neapolitana, built according to the sources by the architect Lucio Cocceio Aucto and several times restructured over the centuries by the Aragonese sovereigns, during the period of the Spanish viceroy and also during the government of the king Carlo of Bourbon (D’Ambra 2012).

Dimandasi questa Grotta di Pozzoli, come quella, che fu fatta per andar più comodamente da Napoli a quella Città, senza impegnarsi col mare, o pure senza ascendere il monte. Autor del cavamento di questo monte fu un tal Coccejio, uomo illustre e ricchissimo (...) Fu ella ampliata dal Re Alfonso Primo di Aragona; e poi da D. Pietro di Toledo Vicerè del Regno di Napoli, per l'Imperatore Carlo V. (Sarnelli 1784, 2; 7)

Central subject within the guides is obviously the archaeological component of the place: the remains of the ancient villas, the thermal complexes, the water tanks like the Piscina Mirabilis, the temples.

The canon Andrea De Jorio, for example, draws up a brief appendix at the beginning of his guide in which he informs the reader of the extraordinary Phlegrean territory, characterized by the presence of so many works that can attract tourists and curious from all over the world.

Le ricchezze del suolo, l'amenità del clima, le vaghe e pittoresche vedute, la felice tranquillità prodotta dal Governo basterebbero ad attirare nel nostro paese ammiratori da tutto il mondo civilizzato; ma ciò che più di ogni altro elettrizza gli spiriti ben formati sì oltramontani, come cittadini, si è l'innumerevole quantità di antichi oggetti, che da per ogni dove s'incontrano, e le grandiose rimembranze da' medesimi ispirate. Pozzuoli, ed i suoi contorni si distinguono fra i luoghi del nostro regno tutti feraci di rimotissime memorie, e ci presentano maestosi ruderi della romana potenza, non che della greca semplicità. (De Jorio 1817, IV)

Already from this first passage, one senses the will to convey the image of a landscape in which nature and archaeology intertwine. The 
ancient ruins, in fact, are carefully described and introduced by brief historical references, but there are also reflections on the precarious state of conservation caused by the infesting vegetation. In addition to the aforementioned Monte Nuovo, another mountain relief often occurs inside the guides, Mount Barbaro, known to the ancients with the name of Gauro, which, often involved during the occurrence of volcanic phenomena, is described by travellers with a particular image desolate and uncultivated, but also as it must have appeared in the eyes of the ancient Romans.

In this context the scholar Lorenzo Palatino, in his work Storia di Pozzuoli e contorni, con breve tratto istorico di Ercolano, Pompei, Stabia e Pesto, of 1826, writes:

Vedesi il famoso monte Gauro nominato attualmente monte Barbaro per la sua ben nota sterilità. Sebbene si è ora principiato a coltivare, e già si ha del vino, bensì in poca qualità, ma generoso e molto nero. Produce (...) uva da noi detta sancinella (...) era un monte rinomato dagli antichi per la ottima qualità del suo vino prodotto nelle falde verso baja e Pozzuolo. (Palatino 1826, 39-40)

This, like many other descriptions, traces the evolution of the mountain, which, as a result of the volcanic activity of the place, lost the ability to produce that much-vaunted wine by the ancients, because of this the name was changed to Barbarian, to further emphasize the poverty of the territory. The sources, therefore, convey a dual image of the territory, the contemporary one and the image of a lost memory.

The observations of Lorenzo Palatino also recount an additional element typical of the Phlegrean landscape, the presence of vineyards still existing today and that especially in the past, have contributed to spread a rather picturesque image of the archaeological ruins of the territory.

Pasquale Panvini, in the work Il Forestiere. Alle Antichità e curiosità naturali di Pozzuoli, Cuma, Baja e Miseno, writes:

La volta piana è così solida, che da più secoli sostiene molta terra vegetabile con vigne, e grossi alberi. Oggi questa piscina serve per gran magazzino di vini. (Panvini 1818, 3) 
And still Lorenzo Palatino, in describing some ancient vestiges, reports in his work:

In queste vicinanze si trova una grotta nominata la grotta della pace (...) Oggi si vede tutta rovinata ed ingombra da terra (...) Il massaro vi racchiude animali, e vi conserva il vino (...) Di questo antico monumento se ne ravvisa ora meno della sua quarta parte, dacché non da molto i coloni lo hanno abbattuto, per formare vigne a scaloni, dette da essi alla procidana. Similmente vanno distruggendo gli altri avanzi de' monumenti. (Palatino $1826,123 ; 223)$

The vineyards end up concealing the ancient ruins as infesting vegetation and moreover, the same monuments are converted into warehouses or partly demolished to allow a better conservation of the wine itself. In addition to the presence of archaeological ruins and vineyards, there are observations concerning the rest of the natural environment of volcanic origin, with a description of the various lakes of the area such as Averno Lake, Lucrino Lake, Fusaro Lake. An interesting aspect especially for the natural environment is that it is always accompanied by the mythological component, which always accompanies the descriptions of the authors who, sometimes in a precise and sometimes approximate way, reconnect the birth of some natural spaces to related events to the most ancient myths.

In the work of Andrea de Jorio, the author is also aware of the vastness of the environment and in the appendix of his guide he advises the traveller different itineraries based on their time spent in the place, an aspect, the latter, which makes the text very contemporary. 
Figure 1. Mons Barbarus

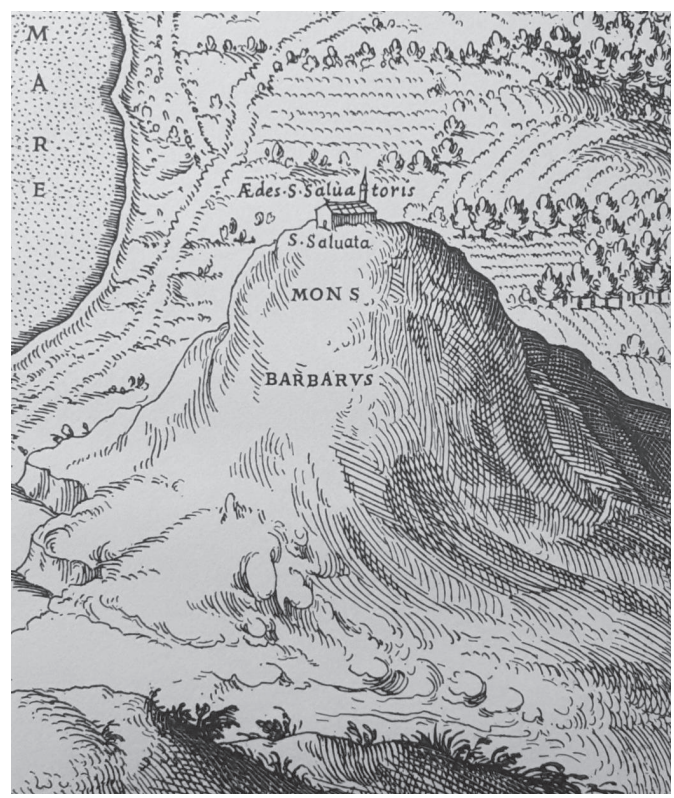

Source: Villamena F. 1985. Ager Puteolanus sive prospectus eiusdem insigniores, ristampa anastatica 1652. Pozzuoli: Nuova Domitia.

\section{THE IMAGE OF THE PHLEGRAEAN FIELDS IN THE DRAWINGS OF PROSPER BARBOT}

\subsection{Prosper Barbot: Voyage d'architecture}

A large contribution to the diffusion of the environment of the Phlegraean Fields is represented by the vast iconographic corpus made by numerous local and foreign architects, who, thanks to their study trips, realize tables and reliefs of the monuments in the area. In this context, Prosper Barbot, French architect and landscape architect of the first half of the XIX century (Schurr, Cabanne 1996), it is part of that class of specialized technicians who reinterpreted the image of the Italian landscape through the drawings kept inside their travel notebooks.

Graduated in the section d'architecture of the École des Beaux-Arts, he, together with some fellow students, makes a first trip to Italy from 1820 
to 1822 , in line with the well-known politics of the école which provided for the completion of the training of the architect through the study trip (D'Alessandro 2002). From this experience, the architect realizes a corpus of six albums, Voyage d'architecture, now kept in the Département des Arts graphiques at the Louvre museum in Paris, where monuments and urban spaces of the peninsula are reproduced. From the album's structure it is possible to reconstruct the different stages of the stay: from Paris to Rome, from August to May 1821, a period during which some drawings of Tuscany are also made; from May to June 1821 in Naples; from June to April 1822 in Rome and in the surrounding areas; from the first of May to the end of July, the return trip to Paris. The drawings of this living room show the typical academic training of an architect trained at the École des Beaux-Arts, in which clear lines describe the architectures and the urban spaces of the territory in an analytical way. The most important nuclei, as regards the number of drawings made, are represented by cities like Rome, of which not only archaeological ruins are shown, central iconographic theme, but also numerous elevations and plants of noble villas, followed by Florence, Naples, with particular attention to the decorations inside the cathedral and the chapel of the treasure of San Gennaro. Even cities such as Spoleto, Narni, Lucca, Pisa, Siena, Venice, Tivoli, just to name a few, attract attention.

In the Campania context, the theme of the ancient is illustrated, in addition to the sketches of the archaeological excavations of Pompeii, from the drawings made in the Phlegraean Fields.

In addition to the well-documented Temple de Sérapis, some of the drawings, such as Plan et coupe de la Piscina Mirabile, Temple polygonal en ruine and Temple de Diane, are part of this section; the latter, in particular, although noted with analytical attention in the different structural parts, shows an image of the landscape, within which the monument has fallen, completely changed with respect to the contemporary urban context. An image, the one recorded by the work of Barbot, which tells the territory of the Phlegraean Fields and in particular that of Baia, now modified by the development of the twentieth century, which has completely lost the picturesque and bucolic appearance of the territory. 


\subsubsection{Prosper Barbot: Voyage de peinture}

From 1826 to 1828 , Prosper Barbot returns to Italy accompanied by his friend Jules Coignet. His way of telling the landscape has completely changed. Certainly influenced by the travelling companion and the knowledge of the landscape painter Camille Corot, he abandoned the academies of the training to return a landscape almost romantic, it is evidence of the choice of the same subjects, in which the architecture is subordinated to the natural landscape (D'Alessandro 2002). To this stay belongs the second corpus of four albums, Voyagede peinture, in which the artist with renewed manner, returns in some of the places of the first trip and then continue south. Beyond Naples and the islands of the gulf, among which Capri presents the largest number of drawings compared to Ischia and Procida, present in the first trip with two drawings, he goes along the Sorrento and Amalfi coast to then arrive in Calabria (Di Teodoro 2000) and Sicily. These places exerted numerous suggestions translated on paper through the realization not only of landscapes but also of studies of boats and trees immersed in an atmosphere made of nuanced tones far removed from the previous production. 
Figure 2: P. Barbot, Temple de Diane, album - paper 42.

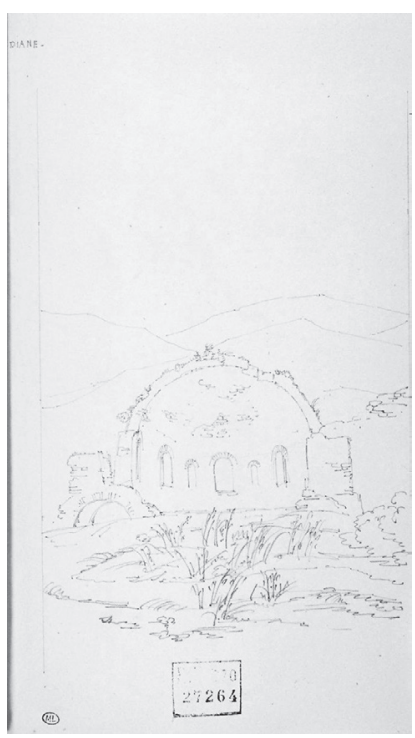

Source: Département des Arts Graphique Louvre (RF 27164).

Figure 3: Diana's temple (2017).

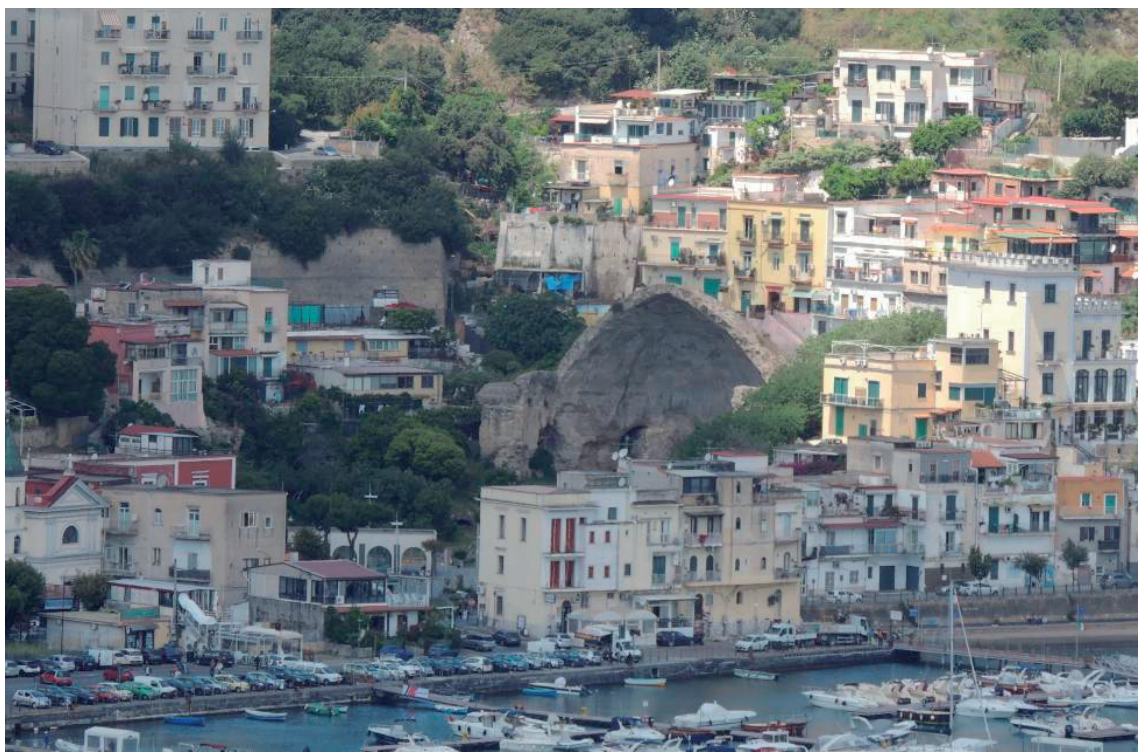

Source: Private collection. 


\section{PHLEGREAN ARCHITECTURE IN THE BOURGEOIS AGE PERIODICALS}

\subsection{Specialized periodicals: new sources of knowledge}

During the nineteenth century many specialized periodicals flourished in the fields of architecture and engineering. This is prompted by the profound transformations that characterized the city, leading to a re-elaboration of the principles, norms and above all of the techniques that could better adapt to the new needs of society. In such a context, it is therefore necessary, a greater accessibility to old and new ideas to deepen their knowledge and eventually make changes.

This act arises within the policy of greater accessibility of knowledge, not only addressed to restricted elites, the basis of the new XIX century culture, a transversal knowledge that can reach the masses to make them participate on the debates of the new operational cultural climate. Among the various communication tools, the magazine is the most suitable means for this purpose, a more than a valid tool for the circulation of ideas.

In regards to the fields of architecture and engineering, numerous periodicals are published throughout the peninsula as «Il Politecnico» (Milano 1839-1869), «Il Giornale dell'Ingegnere Architetto e Agronomo» (Milano 1853-1868), «L'Ingegneria civile e le arti industriali» (Torino 18751906), «Ricorsi di Architettura» (Firenze 1878-1900), «L’Edilizia Moderna. Periodico mensile di architettura pratica e costruzioni» (Milano 18921903). The Neapolitan context was not excluded from these dynamics, from 1833 to 1860 were published the «Annali Civili del Regno delle Due Sicilie», followed by the weekly «Poliorama pittoresco» (1836-1859), which, although with a still encyclopaedic character, shows the first major urban transformations of the city, as well as the annual «La Sirena» (1847-1858), while, more and more technical and specialized in the architectural and engineering field, it characterizes the fortnightly «Polytechnicus» (18931902) and the fortnightly, then monthly "L'Ingegneria Moderna» (19001918). In addition to these "autonomous" sources, there is also that set of periodicals arising in connection with the foundation of the colleges of 
engineers and architects, who, right in the nineteenth century, arise in the major Italian cities.

In this corpus are inserted the "Atti del Collegio degl'Ingegneri e Architetti in Napoli» (1876-1883), subsequently «Bollettino del Collegio degli Ingegneri e Architetti in Napoli» (1883-1905). The periodical, directed in an initial phase by the honorary chief engineer of the Marquis Genius Marchese Gennaro Pepe, was founded with the meeting of 21 February 1876, thanks to the union of two Associations of engineers and architects of Naples: the Architecture Section of the Italian National Association of Scientists, Literati and Artists and the Association of Engineers for Mutual Education. Like many contemporary periodicals, even the Neapolitan Acts, published almost every two months, have a rather complex structure divided into sections: Acts of the College; Memories and relationships; Legislation and Jurisprudence; Scientific, industrial and artistic magazine; Bibliography; obituaries; Competitions-Miscellaneous; Table index. A subdivision, this, which also partly maintained with their conversion into the Bulletin in 1883.

\subsubsection{Architecture in the Flegrei fields: the project Trasformazione in Villa del caseggiato alla spiaggia di Treppetiello, of the engineer Prince Luigi Stragazzi dei Rakoczy}

Among the most important topics present in the Bulletin, there is the question of the right style to be applied to the architectures, there are numerous articles of architects or engineers that, through projects directly written by them or commenting on those of greater resonance, contribute to spread the use of neo-Renaissance style. An example of this construction is planned in the Phlegrean area, close to the Baia'castle, the project Trasformazione in Villa del caseggiato alla spiaggia di Treppetiello, of the engineer prince Luigi Stragazzi dei Rakoczy and the engineer Barone Giacomo Oliva, published by the then-current director of the Bulletin, in 1903. Judged not of particular quality for the size of the works, defined as "little thing" by the designer himself, the intervention was, instead, much appreciated by the College: 
Non è solo nelle opere grandiose che si può ammirare il valore d'un ingegnere, il gusto fine d'un Architetto, ma anche in cose di lievissima importanza, purché trattate in un certo modo. (Oliva 1903, 181)

The article provides an image of the area adjacent to the Baia's castle that does not detach much from that described by the sources of the eighteenth and early nineteenth century, the environment still seems isolated, scarcely anthropized, there is only the presence small communities of fishermen along the coast, which use a rustic building without particular architectural qualities, the only element of modernity seems to be the Cumana railway. The healthy environment suggests the tourist potential of the area, with the hope of returning to the ancient richness of the place:

Dopo il Castello di Baia percorrendo la bella curva del lido si giunge alla marina di Treppetiello. É un arenile dove non si scorge altro che ruderi e un caseggiato in fondo costituito dal piano terreno e il primo piano. Il pianterreno è adibito per deposito d'attrezzi marinareschi e qualche abitazione di marinaio, il primo piano per alloggi di marinai. Il sito è solitario; fin ora non vi è giunto pellegrino se non smarrito; la ferrovia Cumana ha fatto un prodigio, e quale prodigi non fanno oramai le guide di ferro! Baia è ora un centro di villeggiatura e chi sa se un giorno non ritornerà la Baia d'un tempo, la ricca Baia dei conquistatori del mondo. In ogni modo la marina di Treppetiello si trova ai pressi di Baia ed è quanto dire. L'aria è salubre, le acque del mare limpide, la spiaggia irradiata dal Sole. Tutto converge per far ritenere quel sito adatto per una stazione di bagni marini; bagni marini senza tavolato, senza bagnini, senza l'importuno chiamar di numeri che a intervalli uguali e con voce quasi sempre lugubre vi fa sapere che un'altra cabina si è vuotata e voi chinate il capo e pensate(...) come se quelle cabine a somiglianza d'un orologio a sabbia col loro vuotarsi vi volessero dire che così passa la vita! Il vostro bagno è in casa, vi alzate, indossate il costume, fate passi sull'arena e siete in mare, guizzate nell'onda voluttuosa sin vorrete e ritornate in due minuti a casa. (Oliva 1903, 182-183)

The article continues with a careful description of the work to 
be done to convert the group of rustic buildings located along the beach called Treppetiello, in a villa divided into three independent apartments on the lower floor and the upper floor served by a water tank underground. In addition to the successful functional aspects, the building was much appreciated for the architectural style of the façade facing the sea, neoRenaissance with simple mouldings:

Le difficoltà che ha superato non sono state lievi tanto più che ha voluto dare alla facciata un'impronta d'arte con poca spesa e meravigliosamente vi è riuscito. Date uno sguardo alla pianta e all'elevato e ve ne convincerete. Creare in quella massa di fabbricato ambienti, aerati e bene illuminati sembrava cosa impossibile. Egli con molto accorgimento ha ideato la trasformazione di una verticale adibita per abitazione in un ampio cortile come si vede nella piana dove in nero unito è rappresentata la fabbrica esistente, a tratti incrociati più chiari le delimitazioni delle fabbriche esistenti. Con la formazione del cortile al quale si accede direttamente dall'ingresso principale si dà aria e luce a quattordici vani e si disimpegnano le due cucine al pianterreno. Nella parte sotterranea del cortile vi è il serbatoio potabile tutto di bèton a getto di cui in pianta si vede la bocca per attingere l'acqua che proviene dai lastrici. La parte addossata al terrapieno è stata adibita per le cucine. Sono stati demoliti tutti i muri in falso al primo piano e quelli irregolari al pian terreno. Il muro di facciata dal lato che guarda il mare e sua rivolta a Oriente è stato costruito a nuovo. La distribuzione è fatta con comodità utilizzando razionalmente lo spazio disponibile in armonia dei compresi esistenti e con molto gusto architettonico in guisa da formare tre abitazioni indipendenti al primo piano e altrettante al piano superiore con distribuzione quasi identica a quella del piano inferiore. Ognuna di queste abitazioni è costituita da un vestibolo comune, da due salotti, tre grandi camere da letto, un disimpegno, una stanza da pranzo, una ritirata e una cucina con cortile comune coltivato a fiori da servire anche come Hall. (...) Essa guarda verso il mare, i raggi irradiati dal Sole, per quasi una giornata carezzano quelle delicate modanature e gli aggetti proiettano ombre che fanno maggiormente apprezzare la correttezza delle linee che esprimono il sentimento di un soggiorno felice, d'una vita tranquilla, non dolori nè disinganni e nemmeno gioie o illusioni vane, questi sentimenti quelle linee esprimono molto efficacemente con mezzi assai semplici. Non è l'idea preconcetta comune, della ricerca dello stile che ha guidato 
l'architetto, ma ha ascoltato una voce interna che gli ha suggerito come doveva fare e la personalità artistica che non manca mai nelle opere dello Stragazzi si è ancora una volta manifestata. Nel disegno che presentiamo si osservano per solo tono i colori dei materiali impiegati che ne completano l'effetto. Il ravaccione di Carrara, il granito rosso di Baveno e la pietra gialla di Malta sono i principali materiali che costituiscono la bella facciata e ne formano l'accordo armonico, direi quasi l'accompagnamento sul quale si culla il melodioso motivo architettonico. (Oliva 1903, 184)

The building is perfectly integrated into the landscape and designed to be enhanced by the same environment in which it was placed, the decorations on the facade seem to be related to the passage of light that highlights the formal qualities.

This project is part of that set of buildings built between the end of the nineteenth century and the beginning of the twentieth century that characterized the entire Phlegrean area, which, thanks to the Cumana railway, once again became a travel and accommodation destination. 
Figure 4: L. Stragazzi dei Rakoczy, Trasformazione in Villa del caseggiato alla spiaggia di Treppetiello, facade (1903).

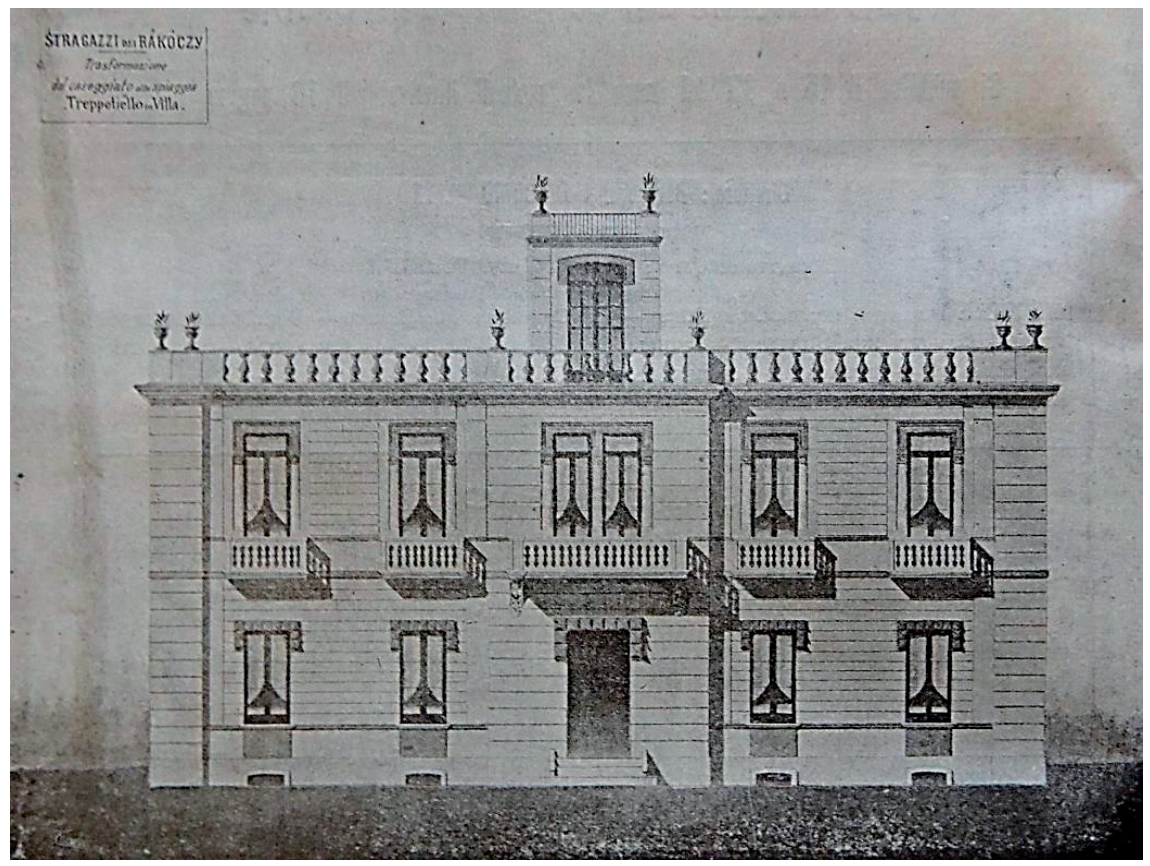

Source: Bollettino del Collegio degli Ingegneri a Architetti in Napoli XXI (13), p. 182. 
Figure 5: L. Stragazzi dei Rakoczy, Trasformazione in Villa del caseggiato alla spiaggia di Treppetiello, plan (1903).

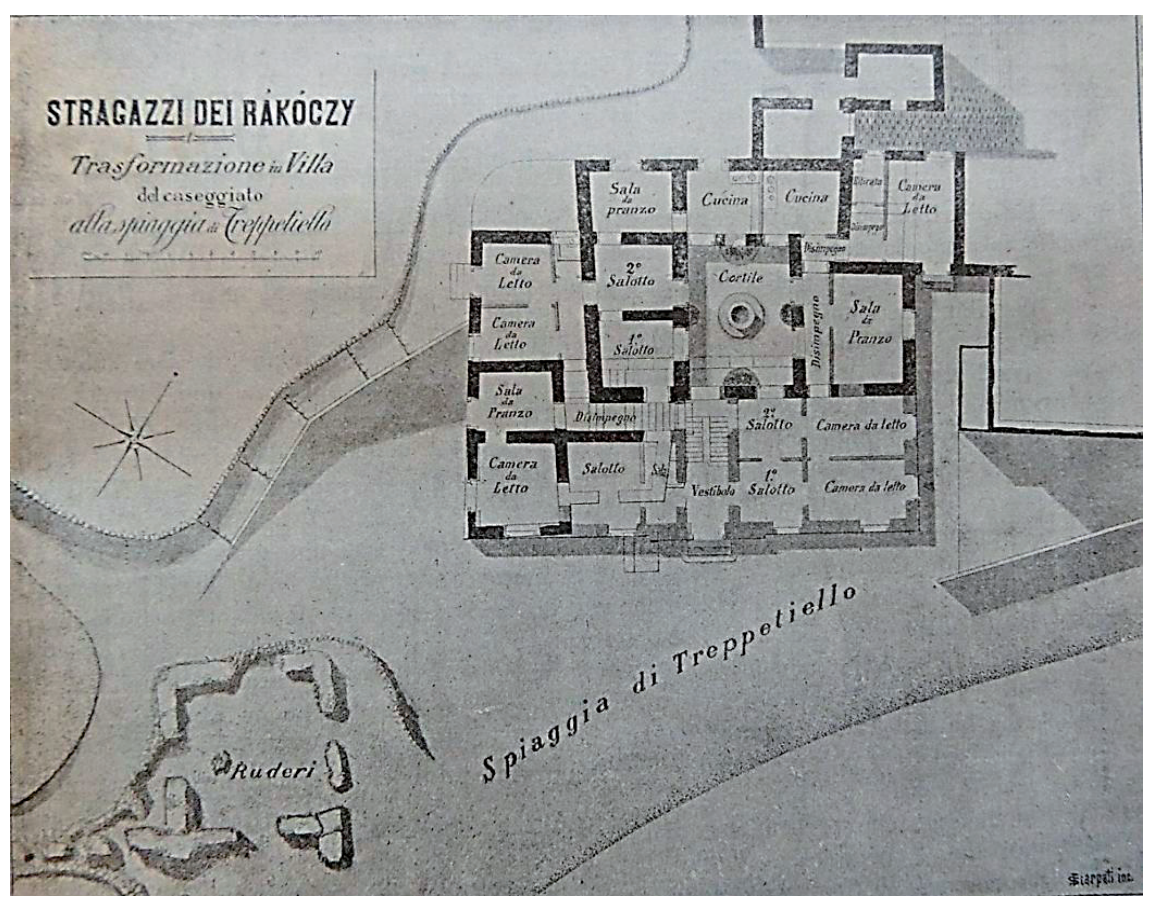

Source: Bollettino del Collegio degli Ingegneri a Architetti in Napoli XXI (13), p. 183.

\section{CONCLUSION}

From the comparison of bibliographical and iconographic sources, it has emerged that the environment of the Phlegraean Fields presents a constantly changing aspect, not only from a geological point of view but above all from an urban point of view. Unfortunately, during the twentieth century, the bucolic aspect, sometimes semi-wild and picturesque of the territory, with its archaeological monuments and its modern bourgeois architecture in perfect balance with the environmental context, progressively disappeared due to uncontrolled building development, concentrated above all along the coastal strip. The latter has certainly undergone most of the urban changes connected to a whole series of work undertaken along the coast to convert an area that has always had 
a strong agricultural and maritime vocation, in a real pole for mechanical and steel production. The ancient archaeological ruins reproduced in the albums of the architect Prosper Barbot, like the temple of Diana, are today drowned by a contemporary building often of poor architectural quality that contributes to spread the image of an environment still of great beauty but disordered. The same architecture of the late nineteenth century is now compressed by the numerous port structures that have also involved an advancement of the coastline, or has almost completely disappeared because of the numerous accretions stratified over time or in most cases demolished in function of building new houses. 


\section{REFERENCES}

D’alessandro G. 2002. Prosper Barbot: ricostruzione di una biografia artistica e studio di architetture e vedute napoletane negli inediti Voyage d'Architecture (1820-22) e Voyage de Peinture (1826-28), td in Conservazione dei Beni Architettonici e Ambientali, Università degli Studi Mediterranea, 43-50. Reggio Calabria.

D’Ambra R. 2012. Napoli Antica. Illustrata con 118 tavole in cromo litografia, (ristampa anastatica ed. 1889), TAV. LXXX. Napoli: Grimaldi e C. Editori.

D’Ambrosio A. 1976. Storia della mia terra, 25. Pozzuoli: Centro Turistico Giovanile.

De Jorio A. 1817. Guida di Pozzuoli e contorno, IV, Napoli: Giovanni de Bonis.

Di Liello S. 2005. Il paesaggio dei campi flegrei. Realtà e metafora, 11. Napoli: Electa Napoli.

Di Liello S. 2009. 'Pozzuoli'. In I centri storici della provincial di Napoli: Struttura, forma, identità urbana, Napoli: Edizioni Scientifiche Italiane.

Di Teodoro F. P. 2000. 'In Calabria nel 1826. I luoghi nelle vedute di Prosper Barbot (1798-1878)'. In 1734-1861, i Borbone e la Calabria: temi di arte, architettura, urbanistica, 47-51. Roma: Edizioni De Luca.

Giamminelli R. 1987. Il centro antico di Pozzuoli: Rione Terra e Borgo, 39. Napoli: S. Civita Dick Peerson.

Mazzella S. 1591. Sito, et antichità della città di Pozzuolo, e del suo amenissimo distretto. Con la descrittione di tutti i luoghi notabili, e degni di memoria, e di Cuma, e di Baia, e di Miseno, e de altri luoghi convicini, 44-45. Napoli: Horatio Salviani.

Oliva G. 1903. 'Stragazzi dei Rakòczy, Trasformazione in Villa del caseggiato alla spiaggia di Treppetiello'. In Bollettino del Collegio degli Ingegneri a Architetti in Napoli XXI (13): 181-184.

Palatino L. 1826. Storia di Pozzuoli e contorni, con breve tratto istorico di 
Ercolano, Pompei, Stabia e Pesto, 39-40. Napoli: Dalla Tipografia di Luigi Nobile.

Panvini P. 1818. Il Forestiere. Alle Antichità e curiosità naturali di Pozzuoli, Cuma, Baja e Miseno, 3. Napoli: Presso Niccola Gervasi al Gigante.

Sarnelli, P. 1784. La Guida de' forestieri, curiosi di vedere, e di riconoscere le cose più memorabili di Pozzuoli, Baja, Cuma, Miseno, Gaeta. Ed altri luoghi circonvicini, V ed. pp., Napoli.

Schurr G., Cabanne P. 1996. Dictionnaire des petits maîtres de la peinture, 80-81. Paris: les edictions de l'amateur.

Von Goethe J. W. 1875. Ricordi di viaggio in Italia nel 1786-87, traduzione dal tedesco di Augisto di Cossilla, 206. Milano: Tipografia Librario Ditta Editrice F. Manini. 